\title{
Long-term follow-up results of corneal collagen cross-linking in keratoconus
}

\section{Keratokonusta korneal kollajen çapraz-bağlama tedavisinin uzun dönem sonuçları}

Ayşe Ebru Kılavuzoğlư ${ }^{1}$, Ali Rıza Cenk Çelebi ${ }^{1}$, Cemile Banu Coşar $^{1}$, Asım Bozkurt Şener ${ }^{2}$

\section{ABSTRACT}

Objective: To evaluate the changes in corneal parameters (keratometry, corneal thickness, topography indices) after corneal collagen cross-linking in keratoconus.

Methods: The medical records of 6 patients who underwent corneal collagen cross-linking treatment for keratoconus and have been followed-up for a minimum of 24 months were recruited. Best corrected visual acuity (BCVA), maximum keratometry (Kmax), central corneal thickness (CCT) values and corneal topography indices: index of surface variance (ISV), index of vertical asymmetry (IVA), keratoconus index (KI), central keratoconus index $(\mathrm{CKI})$, minimum radius of curvature (Rmin), index of height asymmetry (IHA), and index of height decentralisation (IHD) were recorded.

Results: The mean preoperative Kmax value was $46.67 \pm 4.15$ (43.30-57.10) D and the mean Kmax value at the final postoperative visit was $45.41 \pm 2.95$ (43.00-53.20) D. Mean preoperative CCT was 494.70 \pm 33.69 (438-537) $\mu \mathrm{m}$ and final postoperative mean CCT was $495.60 \pm 34.99$ (433-539) $\mu \mathrm{m}$. The deterioration in corneal topography indices stopped during the follow-up period of each case.

Conclusion: Stopping the deterioration of corneal parameters in keratoconus is the desired outcome after crosslinking treatment. Our results found an improvement or at least stabilization in all topography indices in keratoconus patients. J Clin Exp Invest 2015; 6 (4): 343-350

Key words: Keratoconus, corneal collagen cross-linking, corneal topography

\section{INTRODUCTION}

Keratoconus is a disease of the cornea characterized by progressive corneal stromal thinning and ectasia. Many treatment options like spectacles, contact lenses and keratoplasty are performed for the consequences of this disease. Besides these treatments, corneal collagen cross-linking address-

\section{ÖZET}

Amaç: Keratokonusta kornea kollajen çapraz bağlama sonrası kornea parametreleri (keratometre, kornea kalınIığı, topografi indeksleri) değişikliklerini değerlendirmek.

Yöntemler: Keratokonus için korneal kollajen çapraz bağlama tedavisi uygulanan ve en az 24 ay takip edilen 6 hastanın tıbbi kayıtları çalışmaya alındı. En iyi düzeltilmiş görme keskinliği (EİDK), maksimum keratometri (Kmax), santral kornea kalınlığı (SKK) ve korneal topografi indeksleri: Yüzey Varyans indeksi (ISV), dikey asimetri indeksi (IVA), keratokonus indeksi (KI), merkez keratokonus indeksi (CKI), minimum eğrilik yarıçapı (Rmin), yükseklik asimetrisi indeksi (IHA) ve yükseklik desantralizasyon indeksi (IHD) kaydedildi.

Bulgular: Ameliyat öncesi Kmax değeri 46,67 $\pm 4,15$ (43.30-57.10) D ve ameliyat sonrası nihai ziyarette ortalama Kmax değeri 45.41 2.95 (43.00-53.20) D. Preoperatif SKK 494,70 33,69 (438-537) $\mu \mathrm{m}$ idi ve nihai postoperatif

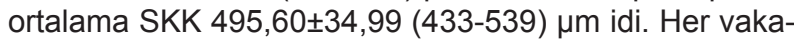
da korneal topografi indekslerindeki bozulma takip süresi boyunca durdu.

Sonuç: Keratokonusta kornea parametrelerinin bozulmasını durdurmak çapraz bağlama tedavisinden sonra arzu edilen sonuçtur. Bizim çalışmamızın sonucunda keratokonus hastalarının tüm topografi indekslerinde iyileşme veya en azından stabilite saptanmıştır.

Anahtar kelimeler: Keratokonus, korneal kollajen çapraz bağlama, kornea topografisi.

es the pathophysiology of keratoconus and aims to stop the progression of this disease. Thus, this method of treatment lowered anxiety and improved vision-related and health-related quality of life in keratoconus patients [1].

Cross-linking forms new covalent bonds between collagen fibrils and thus increases the biomechanical stability of the cornea [2]. After cross-

${ }^{1}$ Acibadem University School of Medicine Ophthalmology Department istanbul, Turkey

${ }^{2}$ Dunya Goz Hospital, Etiler, İstanbul, Turkey

Correspondence: Ayşe Ebru Kılavuzoğlu,

Acibadem University School of Medicine Ophthalmology Department İstanbul, Turkey Email: ebrubahadir@gmail.com

Received: 08.10.2015, Accepted: 26.10.2015

Copyright @ JCEI / Journal of Clinical and Experimental Investigations 2015, All rights reserved 
linking treatment there appears to be a keratocyte apoptosis period lasting 2-3 months and thereafter a repopulation occurs $[3,4]$. There may be transient changes in human corneal endothelium following corneal collagen cross-linking [5]. Improved visual acuities, keratometric values and topography indices have been demonstrated in some studies [6-8]. In this retrospective study we aimed to evaluate and depict the changes in corneal parameters (keratometry, corneal thickness, topography indices) for a minimum of 24 months follow-up following conventional corneal collagen cross-linking for progressive keratoconus.

\section{METHODS}

The medical records of the patients who underwent cross-linking treatment for keratoconus between April $1^{\text {st }}, 2008$ and February $1^{\text {st }}, 2014$ were reviewed and 10 eyes of 6 patients ( 2 women, 4 men) were included in this retrospective study. The inclusion criteria were; corneal topography pattern consistent with keratoconus, no previous surgery, having a minimum of 24 months follow-up, having had cross-linking treatment for once during the follow-up period, no additional corneal surgeries during the follow-up period, having at least 2 follow-up visits documented during the first year.

The corneal collagen cross-linking procedure was performed by the same surgeon (CBC) as described below. After routine preparation for eye surgeries, $0.5 \%$ proparacaine hydrochloride (Alcaine, Alcon Laboratories, Inc., USA) was instilled for topical anesthesia and the central $8.0 \mathrm{~mm}$ epithelium was scraped with a corneal scarifier. Standard riboflavin $0.1 \%$ (Medio-Cross D, Medio-Haus Medizinprodukte $\mathrm{GmbH}$ ) was instilled every 2 minutes for 30 minutes. The corneal penetration of riboflavin was confirmed with visualization of the yellow colored riboflavin in the anterior chamber with a slit-lamp. CCT was measured with an ultrasonic pachymetry (Accutome AccuPach VI Pachymeter, Accutome Inc., Malvern, USA). If the corneal thickness was less than $400 \mu \mathrm{m}, 1$ drop of hypotonic riboflavin $0.1 \%$ (MedioCross $\mathrm{H}$, Medio-Haus Medizinprodukte $\mathrm{GmbH}$ ) was administered every 10 seconds for 2 minute sessions, after which ultrasound pachymetry was performed to confirm that the stroma was swollen to $400 \mu \mathrm{m}$ or thicker. The procedure was proceeded by starting $365 \mathrm{~nm}$ UVA radiation (UV-X system, IROC AG, Zurich, Switzerland) at an irradiance of $3.0 \mathrm{~mW} / \mathrm{cm} 2$. By adjusting the aperture, only the non-epithelialized cornea was irradiated and the limbal stem cells were avoided.
During the application of UVA radiation standard riboflavin $0.1 \%$ was also instilled every 2 minutes. For some of the patients' isotonic riboflavin (MedioCross $\mathrm{M}$, Medio-Haus Medizinprodukte $\mathrm{GmbH}$ ) was used in all parts of the procedure. When the 30 minutes of radiation treatment was over, the cornea was washed thoroughly with BSS. One drop of an antibiotic and a bandage contact lens were put on the eye. Contact lens was removed after epithelial healing. For the postoperative 1st week; treatment regimen was moxifloxacin hydrochloride ophthalmic solution $0.5 \%$ (Vigamox®, Alcon Laboratories, Inc., USA) 3 times daily, nepafenac ophthalmic suspension $0.1 \%$ (Nevanac $\AA$, Alcon Laboratories, Inc., USA) 3 times daily and artificial tear drops (Refresh $®$, Allergan Laboratories, Inc., USA) every hour. For the 2nd postoperative week loteprednol etabonate ophthalmic suspension $0.5 \%$ (Lotemax $\circledR$, Bausch\&Lomb, Inc., Florida, USA) was used 4 times daily and artificial tear drops were used as needed. Lotemax $®$ was tapered and discontinued during the following 2 weeks.

The objective refraction measurements were taken by Topcon KR 8900 Auto-Kerato-Refractometer (Topcon Corporation, Tokyo, Japan), the CCT and the keratometry values were obtained using Pentacam (Oculus Optikgeräte $\mathrm{GmbH}$, Wetzlar, Germany), corneal topography indices were obtained by Wavelight-Allegretto Wave Topolyzer (WaveLight Technologie, AG, Erlangen, Germany). The best corrected visual acuity (BCVA) before the operation and at the final visit; Kmax, CCT values and topography indices: ISV, IVA, KI, CKI, Rmin, IHA, and IHD at each visit were recorded. The abnormal and pathologic values for these indices are presented in Table 1 [9].

Table 1. Abnormal and pathological values for the topography indices (Wave light-Allegretto Wave Topolyzer, WaveLight Technologie, AG, Erlangen, Germany).

\begin{tabular}{lcc}
\hline Index & Abnormal & Pathological \\
\hline ISV & $\geq 37$ & $\geq 41$ \\
IVA & $\geq 0.28$ & $\geq 0.32$ \\
KI & $\geq 1.07$ & $\geq 1.07$ \\
CKI & $\geq 1.03$ & $\geq 1.03$ \\
Rmin & $<6.71$ & $<6.71$ \\
IHA & $\geq 19$ & $>21$ \\
IHD & $\geq 0.014$ & $\geq 0.016$ \\
\hline
\end{tabular}

$\mathrm{CKI}$ : central keratoconus index; IHA: index of height asymmetry; IHD: index of height decentration; ISV: index of surface variance; IVA: index of vertical asymmetry; $\mathrm{KI}$ : keratoconus index; Rmin: minimum radius of curvature 


\section{RESULTS}

The mean age of the patients was $24.83 \pm 3.54$ (range 20 - 28) years. The follow-up ranged from 24 to 63 months with a mean follow-up of $38 \pm 13.08$ months. Table 2 shows the preoperative and final postoperative measurements for BCVA, Kmax, CCT,
ISV, IVA, KI, CKI, Rmin, IHA and IHD. The mean preoperative Kmax value was 46.67 \pm 4.15 (43.3057.10) $\mathrm{D}$ and final postoperative mean Kmax value was 45.41 \pm 2.95 (43.00-53.20) D. Preoperative mean CCT was 494.70 \pm 33.69 (438-537) $\mu \mathrm{m}$ and final postoperative mean CCT was $495.60 \pm 34.99$ (433-539) $\mu \mathrm{m}$.

Table 2. Preoperative and postoperative measurements for each eye

\begin{tabular}{|c|c|c|c|c|c|c|c|c|c|c|c|c|c|}
\hline & & & & BCVA & Kmax & ССТ & ISV & IVA & KI & CKI & Rmin & IHA & IHD \\
\hline Case & Laterality & Age & Follow-up & $\begin{array}{l}\text { Preop } \\
\text { Postop }\end{array}$ & $\begin{array}{l}\text { Preop } \\
\text { Postop }\end{array}$ & $\begin{array}{l}\text { Preop } \\
\text { Postop }\end{array}$ & $\begin{array}{l}\text { Preop } \\
\text { Postop }\end{array}$ & $\begin{array}{l}\text { Preop } \\
\text { Postop }\end{array}$ & $\begin{array}{l}\text { Preop } \\
\text { Postop }\end{array}$ & $\begin{array}{l}\text { Preop } \\
\text { Postop }\end{array}$ & $\begin{array}{l}\text { Preop } \\
\text { Postop }\end{array}$ & $\begin{array}{l}\text { Preop } \\
\text { Postop }\end{array}$ & $\begin{array}{l}\text { Preop } \\
\text { Postop }\end{array}$ \\
\hline \multirow{2}{*}{1} & \multirow{2}{*}{$\mathrm{R}$} & \multirow{2}{*}{25} & \multirow{2}{*}{24} & 0.5 & 45.50 & 438 & - & - & - & - & - & - & - \\
\hline & & & & 0.9 & 44.90 & 438 & 49.00 & 0.42 & 1.12 & 1.06 & 6.75 & 15.40 & 0.0270 \\
\hline \multirow{4}{*}{2} & \multirow{2}{*}{$\mathrm{R}$} & \multirow{4}{*}{21} & \multirow{2}{*}{29} & 0.5 & 45.50 & 508 & 81.00 & 0.99 & 1.23 & 1.05 & 6.43 & 87.30 & 0.0750 \\
\hline & & & & 0.4 & 45.90 & 510 & 68.00 & 0.71 & 1.19 & 1.05 & 6.72 & 84.30 & 0.0620 \\
\hline & \multirow{2}{*}{ L } & & \multirow{2}{*}{24} & 1.0 & 43.30 & 525 & 29.00 & 0.27 & 1.07 & 1.02 & 7.46 & 10.20 & 0.0140 \\
\hline & & & & 0.9 & 43.00 & 485 & 25.00 & 0.17 & 1.05 & 1.02 & 7.47 & 10.30 & 0.0100 \\
\hline \multirow{4}{*}{3} & \multirow{2}{*}{$\mathrm{R}$} & \multirow{4}{*}{28} & \multirow{2}{*}{42} & 0.5 & 43.70 & 476 & 46.00 & 0.46 & 1.10 & 1.04 & 6.70 & 44.20 & 0.0430 \\
\hline & & & & 0.7 & 44.50 & 512 & 38.00 & 0.40 & 1.10 & 1.03 & 6.90 & 46.40 & 0.0380 \\
\hline & \multirow{2}{*}{ L } & & \multirow{2}{*}{42} & 0.5 & 44.40 & 492 & 52.00 & 0.64 & 1.14 & 1.01 & 6.76 & 48.80 & 0.0530 \\
\hline & & & & 1.0 & 43.10 & 505 & 43.00 & 0.55 & 1.12 & 1.00 & 7.03 & 49.30 & 0.0430 \\
\hline \multirow{2}{*}{4} & \multirow[b]{2}{*}{$L$} & \multirow{2}{*}{28} & \multirow{2}{*}{48} & 0.8 & 47.50 & 472 & - & - & - & - & - & - & - \\
\hline & & & & 0.8 & 46.30 & 505 & 72.00 & 0.92 & 1.22 & 1.01 & 6.45 & 87.50 & 0.0730 \\
\hline \multirow{4}{*}{5} & \multirow{2}{*}{$\mathrm{R}$} & \multirow{4}{*}{27} & \multirow{2}{*}{36} & 0.6 & 50.00 & 509 & 65.00 & 0.56 & 1.12 & 1.05 & 6.23 & 43.10 & 0.0450 \\
\hline & & & & 0.4 & 45.30 & 500 & 55.00 & 0.47 & 1.11 & 1.04 & 6.42 & 31.70 & 0.0360 \\
\hline & \multirow{2}{*}{ L } & & \multirow{2}{*}{24} & 0.8 & 44.50 & 537 & 35.00 & 0.43 & 1.11 & 1.01 & 7.10 & 36.90 & 0.0320 \\
\hline & & & & 0.6 & 43.70 & 539 & 33.00 & 0.40 & 1.09 & 1.01 & 7.16 & 35.40 & 0.0300 \\
\hline \multirow{4}{*}{6} & \multirow{2}{*}{$\mathrm{R}$} & \multirow{2}{*}{20} & \multirow{2}{*}{48} & 0.16 & 57.10 & 456 & - & - & - & - & - & - & - \\
\hline & & & & 0.4 & 53.20 & 433 & 95.00 & 0.90 & 1.24 & 1.08 & 5.68 & 69.70 & 0.0830 \\
\hline & \multirow{2}{*}{ L } & & C & 0.7 & 45.20 & 534 & - & - & - & - & - & - & - \\
\hline & & & 63 & 1.0 & 44.20 & 529 & 30.00 & 0.35 & 1.09 & 1.00 & 7.14 & 25.10 & 0.0270 \\
\hline
\end{tabular}

R: right eye; L: left eye; BCVA: best corrected visual acuity; Kmax: maximum keratometry; CCT: central corneal thickness; CKI: central keratoconus index; IHA: index of height asymmetry; IHD: index of height decentration; ISV: index of surface variance; IVA: index of vertical asymmetry; KI: keratoconus index; Rmin: minimum radius of curvature

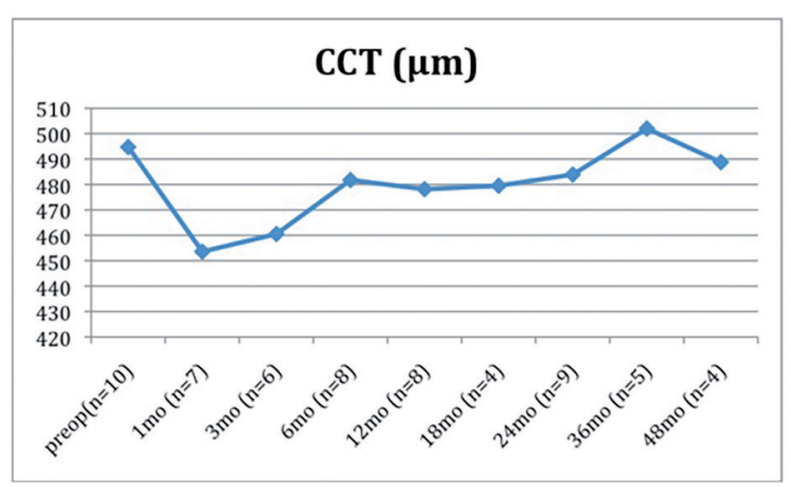

Figure 1. Change in central corneal thickness (CCT) values over time

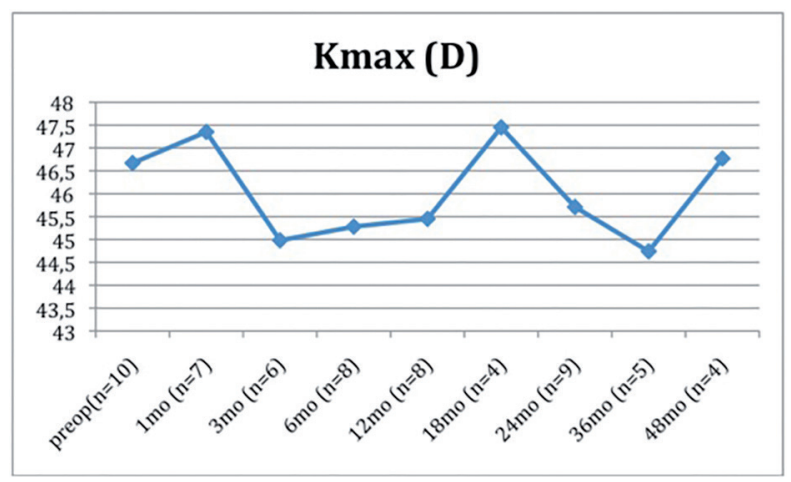

Figure 2. Change in maximum keratometry (Kmax) values over time 
Change in mean CCT, Kmax and topography indices over time are shown in Figure 1,2 and 3 respectively. As a representative case Pentacam derived preoperative and postoperative corneal thickness maps of right eye of case 3 are shown in
Figure 4 and Wave light-Allegretto Wave Topolyzer derived preoperative and postoperative corneal topography maps of right eye of case 3 are shown in Figure 5.

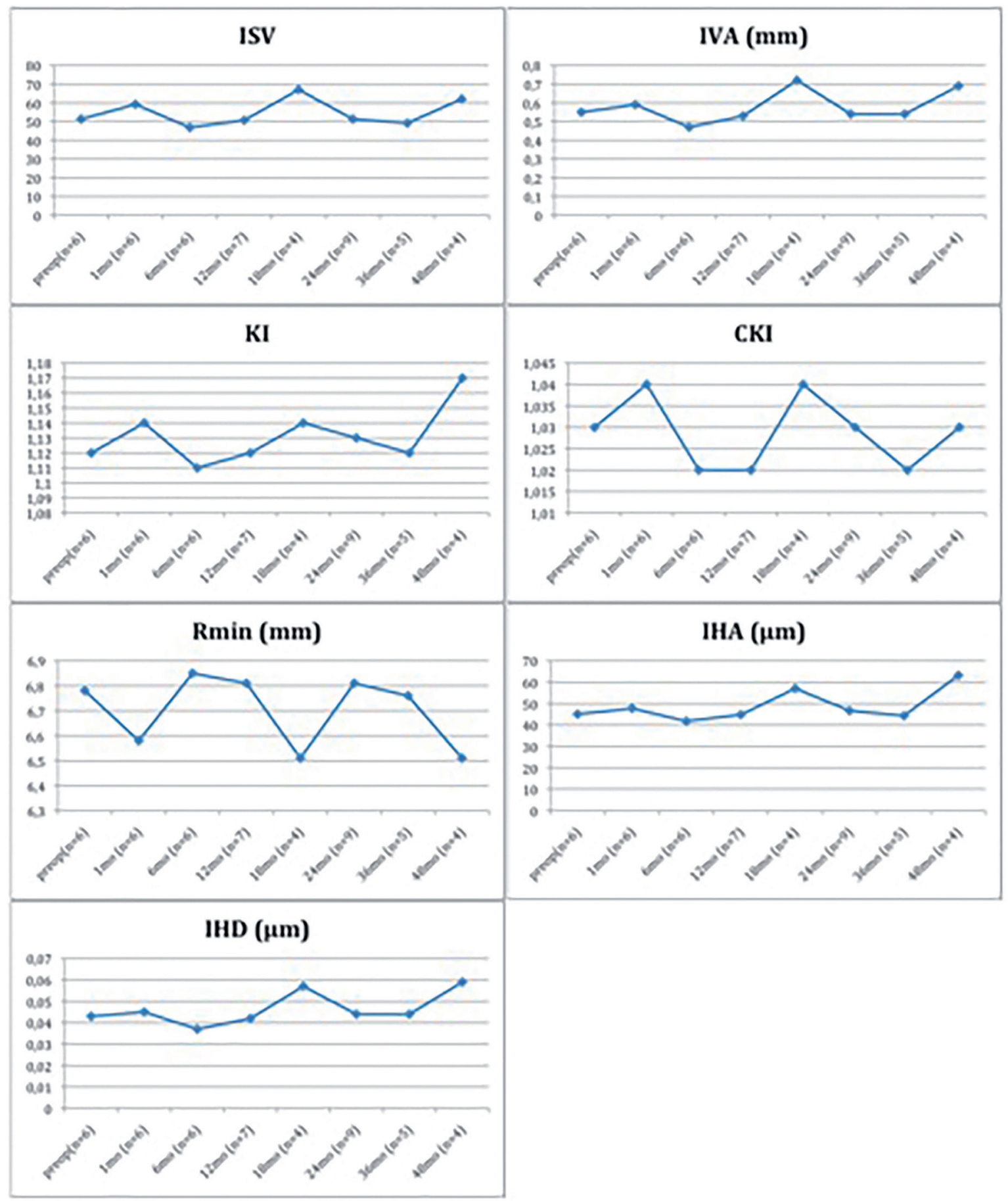

Figure 3. Change in topography indices over time after cross-linking. Index of surface variance (ISV), index of vertical asymmetry (IVA), keratoconus index (KI), central keratoconus index (CKI), minimum radius of curvature (Rmin), index of height asymmetry (IHA), index of height decentration (IHD) 


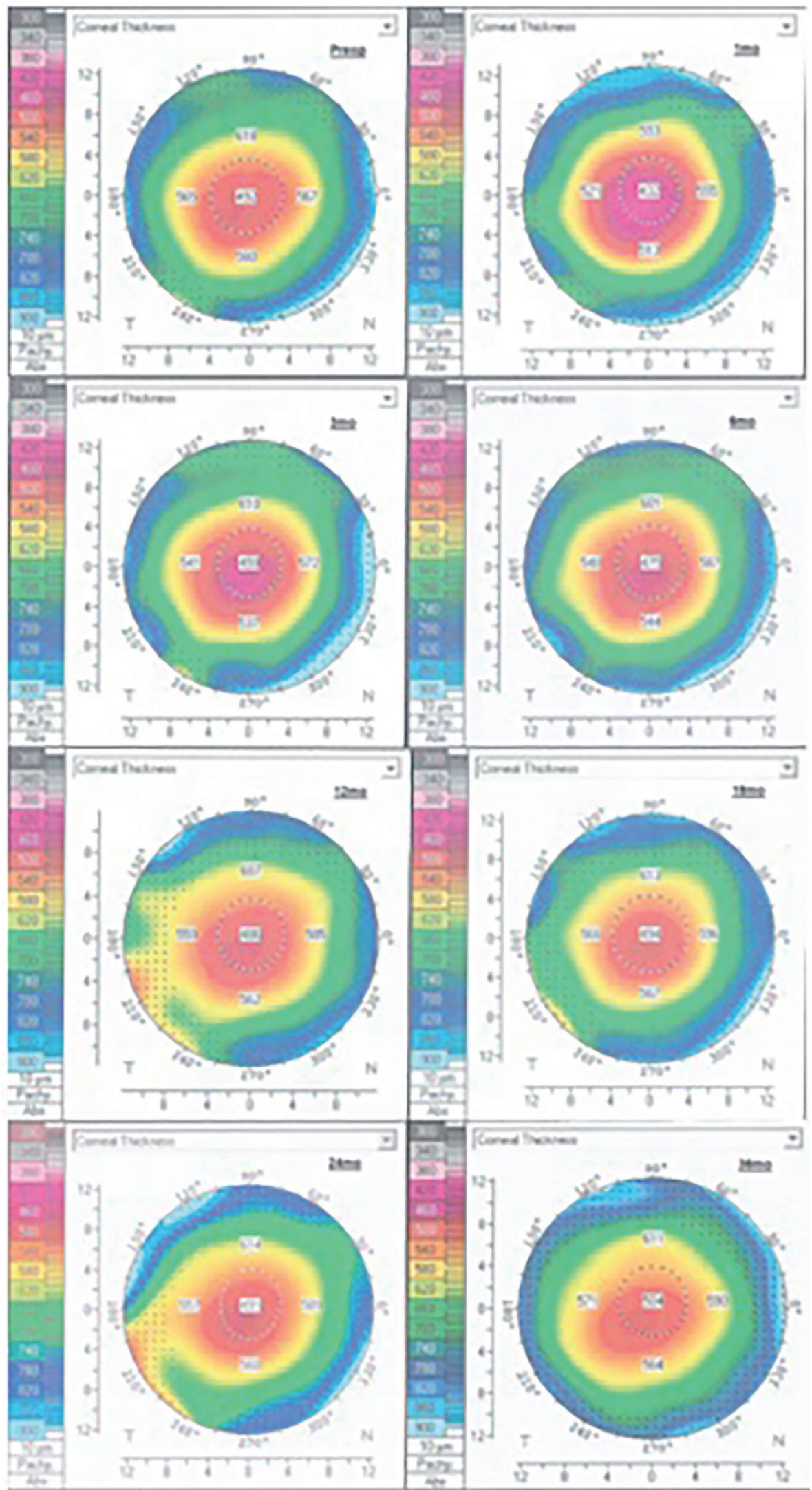

Figure 4. Preoperative and postoperative corneal thickness maps of right eye of case 3 


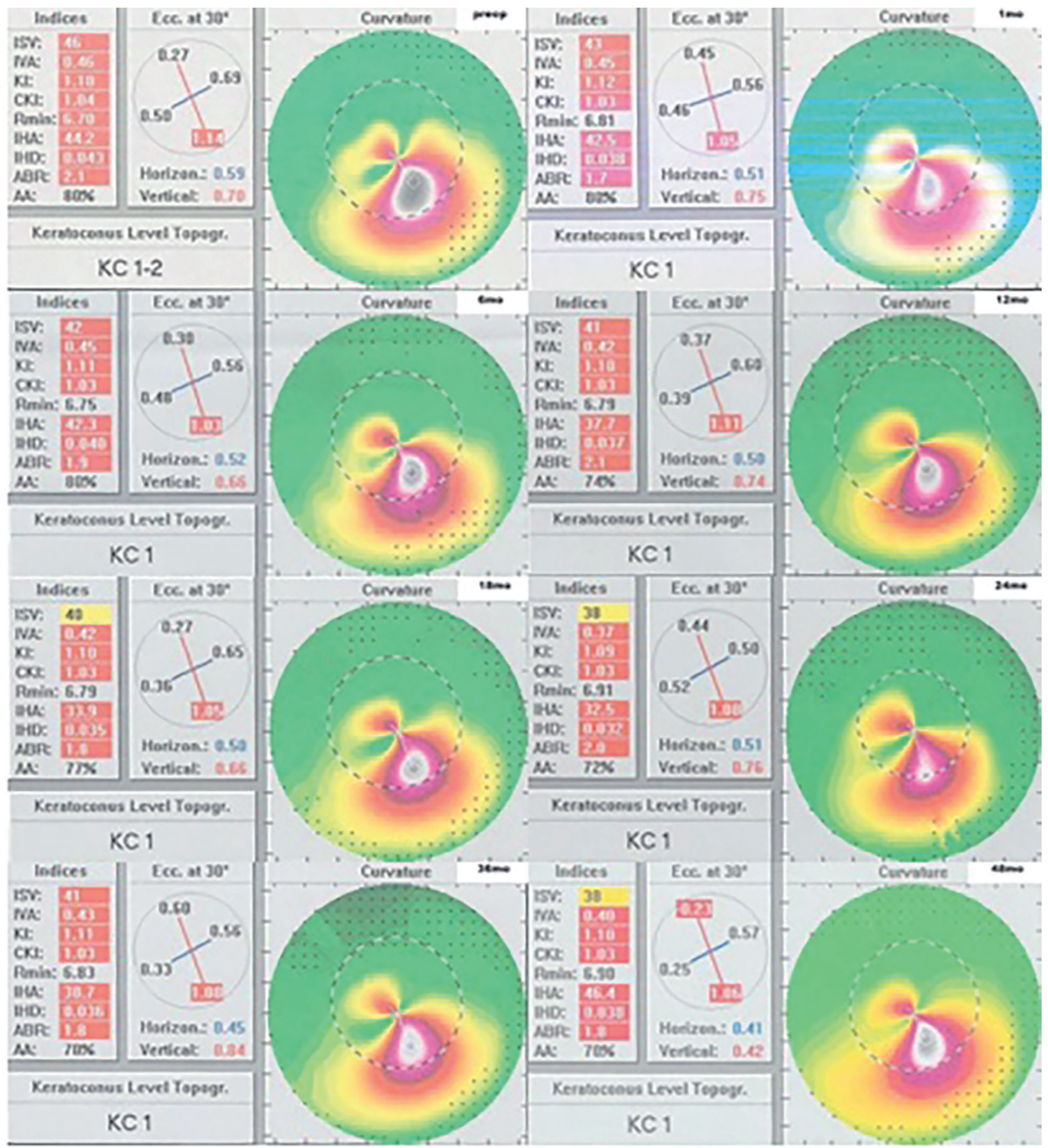

Figure 5. Preoperative and postoperative corneal topography maps and topography indices of right eye of case 3

\section{DISCUSSION}

Progressive thinning and bulging of the cornea is the main concern in follow-up and treatment of keratoconus. Increase in keratometric values, thinning of the cornea and deterioration of the corneal topography indices are observed in this disease course.
Stopping the increase or deterioration of these parameters is the main goal of the treatment.

Corneal collagen cross-linking arrests the progression of keratoconus by increasing the biomechanical stability of the cornea [2,10-12]. This is achieved by formation of new covalent links between collagen fibrils. The findings in this study 
show that the Kmax, CCT and corneal topography indices remain steady even after a follow-up of 2463 months.

Contact lenses had been described to arrest keratoconus but it hasn't been confirmed in a systematic study [13]. There are some studies showing the arrest of keratoconus by corneal collagen cross-linking in which no significant change was observed in keratometry values during the follow-up period $[8,14,15]$. Also some studies report improvement in keratometry readings and visual acuities after cross-linking treatment $[5,16,17]$. Wittig-Silva et al. reported a decrease in keratometry values of $0.72 \pm 0.15 \mathrm{D}$ in postoperative 1 st year and this decrease increased to $1.03 \pm 0.19 \mathrm{D}$ in 3rd year [18]. In this study the mean Kmax values didn't differ from the preoperative values at the end of follow-up period.

There are some different modifications in corneal collagen cross-linking particularly to reduce the treatment time. Accelerated corneal collagen crosslinking became popular nowadays and has similar results with the conventional one $[19,20]$.

The final postoperative mean CCT was nearly the same as the preoperative values in this study. Although most of the studies in the literature documented no statistically significant change in corneal thickness between preoperative and postoperative values, there are some others reporting significant decrease in corneal thickness after cross-linking treatment [18-24]. Performing corneal cross-linking procedure with isotonic riboflavin solution without dextran might not induce corneal thinning but a little swelling throughout the procedure. This could also be taken into consideration while evaluating the CCT [25]. Arbelaez et al. demonstrated a transient initial decrease in corneal thickness and after 3 months they observed a steady increase up to preoperative values [3]. To the best of our knowledge the retrospective study of Raiskup-Wolf et al. was the only study which demonstrated a significant increase in corneal thickness 2 years after crosslinking $(+21 \pm 31 \mu \mathrm{m})[6]$.

The main limitation of the study was the number of patients that were examined. It was hard to follow-up a patient for two years because after succesful corneal collagen cross-linking treatment the patient thought that disease was over. The other limitation was the retrospective nature of the study. Both of these limitations can be outreached with over two year prospective large group cohort studies in the future.
The stabilization and improvement in corneal topography indices were also shown in some previous studies. Sloot et al. found significant improvements in ISV, IVA, CKI, Rmin and IHD one year after cross-linking [26]. Toprak et al. demonstrated improvements in ISV, CKI and Rmin after cross-linking with a follow-up of 12 months [27]. Here in this study we found an improvement or at least stabilization in all topography indices for every case.

In conclusion, this study demonstrates the stability of corneal topographic parameters after 3 years mean follow-up period following conventional corneal collagen cross-linking for the treatment of progressive keratoconus.

\section{REFERENCES}

1. Cingu AK, Bez $Y$, Cinar $Y$, et al. Impact of collagen cross-linking on psychological distress and vision and health-related quality of life in patients with keratoconus. Eye Contact Lens 2015;41:349-353.

2. Wollensak G. Crosslinking treatment of progressive keratoconus: new hope. Curr Opin Ophthalmol 2006;17:356-360.

3. Arbelaez MC, Sekito MB, Vidal C, Choudhury SA. Collagen cross-linking with riboflavin and ultraviolet-A light in keratoconus: one-year results. Oman J Ophthalmol 2009;2:33-38.

4. Wollensak G, Spoerl E, Reber F, Seiler T. Keratocyte cytotoxicity of riboflavin/UV-A treatment in vitro. Eye 2004;18:718-722.

5. Cingü AK1, Sogutlu-Sari E, Cınar Y, et al. Transient corneal endothelial changes following accelerated collagen cross-linking for the treatment of progressive keratoconus. Cutan Ocul Toxicol 2014;33:127-131.

6. Raiskup-Wolf F, Hoyer A, Spoerl E, Pillunat LE. Collagen crosslinking with riboflavin and ultraviolet-A light in keratoconus: long-term results. J Cataract Refract Surg 2008;34:795-801.

7. Greenstein SA, Fry KL, Hersh PS. Corneal topography indices after corneal collagen crosslinking for keratconus and corneal ectasia: one-year results. J Cataract Refract Surg 2011;37:1282-1290.

8. Hassan Z, Szalai E, Modis L, et al. Assessment of corneal topography indices after collagen crosslinking for keratoconus. Eur J Ophthalmol 2013;23:635-640.

9. WaveLight $\mathrm{GmbH}$. WaveLight ${ }^{\circledR}$ Allegro OculyzerTM 1074 User Manual (English). Erlangen: WaveLight $\mathrm{GmbH} ; 2001$.

10. Wollensak G, Spoerl E, Seiler T. Riboflavin/ultravioleta-induced collagen crosslinking for the treatment of keratoconus. Am J Ophthalmol 2003;135:620-627.

11. Spoerl E, Wollensak G, Seiler T. Increased resistance of cross-linked cornea against enzymatic digestion. Curr Eye Res 2004;29:35-40. 
12. Wollensak G, Spoerl E, Seiler T. Stress-strain measurements of human and porcine corneas after riboflavin- ultraviolet-A-induced cross-linking. J Cataract Refract Surg 2003;29:1780-1785.

13. Rabinowitz YS. Keratoconus. Surv Ophthalmol 1998;42:297-319.

14. Poli M, Cornut PL, Balmitgere T, et al. Prospective study of corneal collagen cross-linking efficacy and tolerance in the treatment of keratoconus and corneal ectasia: 3-year results. Cornea 2013;32:583-590.

15. Hashemi H, Seyedian MA, Miraftab M, et al. Corneal collagen cross-linking with riboflavin and ultraviolet a irradiation for keratoconus: long-term results. Ophthalmology 2013;120:1515-1520.

16. Caporossi A, Baiocchi S, Mazzotta C, et al. Parasurgical therapy for keratoconus by riboflavin-ultraviolet type A rays induced cross-linking of corneal collagen: preliminary refractive results in an Italian study. J Cataract Refract Surg 2006;32:837-845.

17. Viswanathan D, Males J. Prospective longitudinal study of corneal collagen cross-linking in progressive keratoconus. Clin Experiment Ophthalmol 2013; 41:531-536.

18. Wittig-Silva C, Chan E, Islam FM, et al. A randomized, controlled trial of corneal collagen cross-linking in progressive keratoconus: three-year results. Ophthalmology 2014;121:812-821.

19. Cinar Y, Cingu AK, Turkcu FM, et al. Accelerated corneal collagen cross-linking for progressive keratoconus. Cutan Ocul Toxicol. 2014;33:168-171.
20. Cinar Y, Cingu AK, Turkcu FM, et al. Comparison of accelerated and conventional corneal collagen crosslinking for progressive keratoconus. Cutan Ocul Toxicol 2014;33:218-222.

21. Toprak I, Yaylalı V, Yildirim C. Factors affecting outcomes of corneal collagen crosslinking treatment. Eye 2014;28:41-46.

22. Caporossi A, Mazzotta C, Baiocchi S, Caporossi T. Long- term results of riboflavin ultraviolet $A$ corneal collagen cross- linking for keratoconus in Italy: the Siena Eye Cross Study. Am J Ophthalmol 2010;149:585593.

23. Greenstein SA, Shah VP, Fry KL, Hersh PS. Corneal thickness changes after corneal collagen crosslinking for keratoconus and corneal ectasia: one-year results. J Cataract Refract Surg 2011;37:691-700.

24. Vinciguerra P, Camesasca FI, Albe E, Trazza S. Corneal collagen cross-linking for ectasia after excimer laser refractive surgery: 1-year results. J Refract Surg 2010;26:486-497.

25. Cınar $Y$, Cingü AK, Sahin A, et al. Intraoperative corneal thickness measurements during corneal collagen cross-linking with isotonic riboflavin solution without dextran in corneal ectasia. Cutan Ocul Toxicol 2014;33:28-31.

26. Sloot F, Soeters N, van der Valk R, Tahzib NG. Effective corneal collagen crosslinking in advanced cases of progressive keratoconus. J Cataract Refract Surg 2013;39:1141-1145.

27. Toprak I, Yildirim C. Effects of corneal collagen crosslinking on corneal topographic indices in patients with keratoconus. Eye Contact Lens 2013;39: 385-387. 